\title{
A Rosa brasileira que incendiou a questão religiosa em Portugal: o Caso Calmon (1899-1901)
}

\author{
Isabel Corrêa da Silva[1]
}

\begin{abstract}
Resumo
No processo de progressiva secularização da sociedade, que, na Europa e na América, ganhou renovado fôlego a partir de finais do século XIX, as relações entre Estado e Igreja assumiram muitas vezes uma dinâmica conflituosa a que a historiografia convencionou chamar de "questão religiosa". Neste artigo, proponho-me a analisar um momento alto dessa tensão relacional em Portugal a partir de um episódio concreto que, por uma convergência de circunstâncias e predisposições, se transformou num marco simbólico do processo de laicização da sociedade portuguesa. Trata-se da polêmica gerada em torno da vocação religiosa da filha do cônsul do Brasil na cidade do Porto - caso que conduziu a um dos mais acesos e participados debates sobre religiosidade, direitos individuais e confessionalidade do Estado, envolvendo instâncias governamentais e sociedade civil numa mobilização até então nunca vista em assuntos dessa natureza. Anticongreganismo, anticlericalismo e militância laica foram os protagonistas desse episódio, que envolveu cidadãos e chancelarias brasileiras e no qual é possível identificar, com toda a clareza, as linhas de clivagem as quais viriam mais tarde a determinar os contornos da questão religiosa durante o regime republicano, entre 1910 e 1926. Palavras-chave: religião; anticlericalismo; laicismo.
\end{abstract}

\section{La Rosa brasileña que ha inflamado la cuestión religiosa en Portugal: el Caso Calmon (1899-1901)}

\section{Resumen}

En el proceso de secularización progresiva de la sociedad, que, en Europay América, ganó renovada fuerza a partir de finales del siglo 19, las relaciones entre la Iglesia y el Estado tomaron muchas veces una dinámica de conflicto a que la historiografía acordó llamar de "cuestión religiosa". En este artículo, propongo analizar un punto alto de esta tensión relacional en Portugal a partir de un episodio específico que, por una convergencia de circunstancias y predisposiciones, se ha convertido en un marco simbólico del proceso de secularización de la sociedad portuguesa. La polémica en torno a la vocación religiosa de la hija del cónsul de Brasil en Porto es un caso que ha ocasionado uno de los debates más acalorados y concurridos sobre la religiosidad, los derechos individuales y la confesionalidad del Estado, con participación de las instancias gubernamentales y de la sociedad civil en una movilización hasta entonces nunca vista en tales materias. El anticongregacionalismo, el anticlericalismo y la militancia laica fueron los protagonistas de este episodio, que involucró a los ciudadanos y las cancillerías brasileñas. Es posible identificar en ello, con toda claridad, las líneas de división que más tarde determinarían los contornos de la cuestión religiosa durante el régimen republicano, entre 1910 y 1926.

Palabras clave: religión; anticlericalismo; secularismo.

\section{The Brazilian Rosa that upheaved the religious question in Portugal: the Calmon Case (1899-1901)}

\section{Abstract}

In the process of progressive secularization of society, which gained strength after the late 19th century in Europe and America, the relationships between State and Church assumed a conflicting dynamic that historiography began to call “religious question". In this article, I propose to analyze the highpoint of this relational tension in Portugal based on a concrete episode, which, due to a convergence of circumstances and predispositions, became a symbol of the laicization of the Portuguese society. It is the polemic generated around the religious calling of the daughter of a Brazilian consul in Porto - situation that led to one of the most fierce debates about religiousness, individual rights, and confessionality of the State, involving governmental instances and civil society in an unprecedented mobilization in such matters. Anticongreganism, anticlericalism, and laic militancy were the key elements of this episode that involved Brazilian citizens and chancelleries and in which it is possible to clearly understand some of the most important cleavages that would later on determine the outcome of the religious question during the Republican regime, between 1910 and 1926.

Keywords: religion; anticlericarism; laicism.

\section{La Rose brésilienne qui prit feu à la question religieuse au Portugal: l'affaire Calmon (1899-1901)}

Résumé

Dans le processus de sécularisation progressive de la société, qui, en Europe et en Amérique, renouvela son élan à la fin du XIXe siècle, les relations entre l'Église et l'État se présentèrent souvent comme une dynamique conflictuelle que l'historiographie dénomme de «question religieuse». Dans cet article, je me propose d’analyser un point culminant que cette difficile relation prit au Portugal, à partir de létude d'un épisode spécifique qui, par un concours de circonstances et prédispositions, fut érigé en événement marquant pour le processus de sécularisation de la société portugaise. Il śagit de la controverse générée autour de la vocation religieuse de la fille de consul du Brésil à Porto - affaire qui conduisit à un des débats les plus houleux sur la religiosité, les droits individuels et le caractère confessionnel de l'Etat, qui impliqua aussi bien les instances gouvernementales que la société civile en une mobilisation inédite pour ce genre de thèmes. L'anti-congrégationalisme, l'anticléricalisme et le militantisme laïque furent les protagonistes de cet épisode, dans lequel s'engagèrent citoyens et chancelleries brésiliens, et où on peut identifier en toute netteté les lignes de clivage qui devraient plus tard façonner les contours de la question religieuse pendant la $1^{\text {ère }}$ république portugaise, entre 1910 et 1926. Mots clés: religion; anticléricalisme; laïcité. 

vários casos. O Caso das Irmãs da Caridade (1858-1862), o Caso Sara de Matos (1891) e o Caso Calmon (1899-1901) talvez sejam alguns dos mais célebres e paradigmáticos, razão pela qual figuram invariavelmente no índice de qualquer perspectiva global sobre as relações entre Estado, Igreja e sociedade em Portugal. ${ }^{1}$ No fundo, representam três pontos fraturantes do percurso da questão religiosa portuguesa, cuja genealogia pode fazer remontar ao antijesuitismo pombalino de finais dos Setecentos, embora a sua frente verdadeiramente anticlerical — em acelerado caminho para uma militância laica - seja uma realidade que ganha relevância sobretudo a partir de meados do século XIX.

Em 1834, os liberais - vencedores da guerra civil entre absolutistas e liberais que, durante anos, dividiu a sociedade portuguesa — decretaram a extinção das ordens religiosas, o encerramento de todos os conventos, mosteiros, colégios e hospícios e a incorporação dos respectivos bens na Fazenda Nacional. ${ }^{2}$ A alcunha de "Mata Frades", com a qual ficou conhecido o ministro que assinou o decreto de 28 de maio de 1834, Joaquim António Aguiar, e a designação "devoristas", que os contemporâneos atribuíram aos governos de 1834-1836 os quais se ocuparam da venda em hasta pública dos bens da Igreja nacionalizados, indiciam com expressividade o alcance das consequências sociais e econômicas daquela resolução-revolução. ${ }^{3}$

Mas, para além do abalo patrimonial sofrido pelas ordens regulares, o confronto entre legitimistas e liberais teve também implicações ao nível do clero secular. Uma majoritária adesão da comunidade eclesiástica à causa de D. Miguel teve sérias consequências políticas mesmo depois de findo o conflito armado. Muita população rural e do norte do país mobilizou-se contra a nova ordem liberal instalada, dando forma a uma conflitualidade sócio-religiosa que se estendeu, pelo menos, até finais dos anos 1840 e o governo de Costa Cabral. ${ }^{4} \mathrm{O}$ confronto entre clero constitucional e clero ultramontano foi, na verdade, apenas uma das faces da resistência da sociedade tradicional à implementação do projeto regalista e centralizador do liberalismo português.

\footnotetext{
"Uma completa perspectiva sobre o assunto encontra-se em Vítor Neto, O Estado, a Igreja e a sociedade em Portugal (1832-1911), Lisboa, Imprensa Nacional Casa da Moeda, 1998. Cf. também a entrada "Anticlericalismo", de António Matos Ferreira, In: Carlos Moreira Azevedo (dir.), Dicionário de História Religiosa de Portugal, Lisboa, Centro de Estudos de História Religiosa da Universidade Católica Portuguesa; Círculo de Leitores, 2000, p. 79-82.

${ }^{2}$ Decretos de 5 e 9 de agosto de 1833. Decreto de 30 de maio de 1834, que finalmente determina a extinção de todas as casas religiosas masculinas e a nacionalização dos seus bens. Cf. Diário do Governo, 1833, p. 7; 12-13 e Diário do Governo, 1834, p. 70-71.

${ }^{3}$ Veja-se Vasco Pulido Valente, Os Devoristas. A Revolução Liberal: 1834-1836, Lisboa, Quetzal, 1993, bem como Vítor Neto, op cit., p. 62-86.

${ }^{4}$ Como ministro dos Negócios Eclesiásticos e da Justiça, Costa Cabral esforçou-se por implementar uma política de pacificação do "cisma" religioso que, durante a guerra civil (1828-1834), e mesmo depois, dividiu a comunidade eclesiástica nacional entre os padres que se mantiveram fieis à causa legitimista de D. Miguel e os padres que aderiram à nova ordem constitucional defendida por D. Pedro IV. Não obstante, a proibição dos enterramentos no interior das igrejas deu origem a um dos mais célebres levantamentos populares da história portuguesa, que ficou conhecido por Maria da Fonte e que contou com importante apoio do clero miguelista.
} 
Porque a monarquia constitucional não se implementaria à revelia do país, os governos liberais ambicionavam uma subjugação das estruturas eclesiásticas ao poder político de modo a colocar o aparelho religioso ao serviço da nova causa nacional. Naturalmente, não foi de livre ânimo que a Santa Sé viu ser contestado o primado da sua jurisdição sobre as igrejas nacionais. Depois de quase uma década de relações diplomáticas interrompidas, em 1842, Roma e Lisboa reconciliaram-se a partir de um compromisso o qual implicou que o governo português aceitasse a reintegração nas respectivas dioceses de um rol de prelados antiliberais. ${ }^{5}$

\section{Do anticongreganismo ao anticlericalismo: o Caso das Irmãs da Caridade (1858-1862)}

Até meados do século, a questão religiosa portuguesa concentrou-se sobretudo nessa dialética de atrito entre o trono e o altar. Em princípios da década de 1860, o Caso das Irmãs da Caridade surgiu como uma espécie de ponto síntese desta tensão. Na sequência do surto epidémico que atingiu Lisboa entre os anos de 1856-1857, um grupo de Irmãs da Caridade francesas, da congregação de S. Vicente de Paulo, instalou-se na cidade, com excepcional autorização do governo, para dar assistência aos desvalidos. Em 1858, alguma imprensa da capital iniciou uma impiedosa campanha contra as Irmãs, acusando-as de terem extrapolado suas originais funções assistencialistas para se dedicarem também ao ensino. A polêmica foi-se engrandecendo ao ritmo das adesões de novos jornais até que acabou por chegar ao Parlamento. Aqui, ganhou forma de arma política, com o partido da oposição acusando o governo de ser conivente com o incumprimento da lei ao consentir a presença e a atividade de religiosas sujeitas a uma autoridade estrangeira. ${ }^{6}$ O governo reagiu a 3 de setembro de 1858, fazendo sair um decreto que autorizava a permanência das Irmãs no país, com a condição de se limitarem exclusivamente ao exercício de funções de assistência. ${ }^{7}$ Embora aparentasse responder às exigências da opinião pública anticlerical, essa medida esteve longe de conseguir calar a campanha anticongreganista que já se afigurava imparável. O Partido Histórico empenhou-se em assustar a opinião liberal com o fantasma do regresso das ordens religiosas a partir do precedente das

\footnotetext{
${ }^{5}$ Cf. Vítor Neto, O Estado, a Igreja e a sociedade em Portugal (1832-1911), Lisboa, Imprensa Nacional Casa da Moeda, 1998, p. 147.

${ }^{6} \mathrm{~A}$ nacionalidade das "estrangeiras" não foi certamente indiferente, já que, em paralelo com o caso das Irmãs da Caridade francesas, ocorreu uma outra polêmica causada pelo incidente diplomático provocado pelo apresamento da barca francesa Charles et Georges em dezembro de 1857, por suspeita de tráfico de escravos. A questão estendeu-se ao longo do ano de 1858, acabando o governo português por ser obrigado a ceder às pressões internacionais e a libertar o navio e o seu capitão. A questão gerou embaraço político e agravou a indisposição nacional para com a França. Cf. Fortunato de Almeida, A questão do apresamento da barca Charles et George e o Conselho de Estado, Coimbra, [s.n.], 1917. Em carta ao rei da Bélgica, o rei D. Pedro V diz mesmo que, tendo já o país cedido na questão da Charles et Georges, não o poderá fazer em relação às Irmãs da Caridade sem perder a face. Júlio Vilhena, D. Pedro V e o seu reinado, vol. II, Coimbra, Imprensa da Universidade, 1921, p. 205.

7"Decreto de 3 de setembro de 1858", Diário do Governo, p. 347-348.
} 
Irmãs da Caridade. O jornal O Português lançou uma recolha de assinaturas para pedir a expulsão das religiosas. ${ }^{8}$ Em Lisboa, organizaram-se dois comícios anticlericais e criou-se a Associação Promotora da Educação do Sexo Feminino presidida pelas respeitadíssimas figuras de Alexandre Herculano, Oliveira Marreca e Vicente Ferrer Neto Paiva.

O caso das Irmãs da Caridade terminou em 1862 com o regresso das religiosas francesas ao seu país. Paradoxalmente, as consequências do debate gerado pela questão desenvolveram-se em rumos opostos: se, por um lado, a polêmica reforçou a evidência de um anticongreganismo generalizado na sociedade civil, por outro, o caso acabou por servir de impulso para que, por via do restabelecimento do ensino eclesiástico e da assistência pública, paulatinamente se reintroduzissem as ordens religiosas em Portugal. ${ }^{9}$

\section{Do anticlericalismo à militância laica: o Caso Sara de Matos (1891)}

Ao longo das décadas seguintes, o clericalismo foi lançando novas raízes no seio da sociedade portuguesa, ao mesmo tempo em que o anticongreganismo foi reforçando sua feição mais anticlerical. Em inícios dos anos 1890, encontravam-se instaladas em Portugal já cerca de 200 Irmãs Doroteias e 400 Irmãs Hospitaleiras. ${ }^{10}$ Reagindo tanto a esse renascimento da malha clerical como à inflexão conservadora e ultramontana prescrita pela Santa Sé, o antigo secularismo regalista e anticongreganista liberal foi sendo substituído por um anticlericalismo cada vez mais sustentado num proselitismo laico. O sucesso e a popularização de narrativas anticlericais como $O s$ Lazaristas (1875), de António Enes, ou A Velhice do Padre Eterno (1885), de Guerra Junqueiro, mostram como nas últimas décadas do século o ensino religioso ou o caráter extranacional das congregações já não eram o anátema central do anticlericalismo. A mundividência religiosa começou cada vez mais a revelar-se incompatível com uma visão positivista, científica e moderna do mundo, do mesmo modo que os homens e os institutos da Igreja começaram a ser vistos como entraves ao curso da sociedade rumo ao progresso. Sobretudo nos setores urbanos, os dispositivos de demonização que há muito vinham sendo utilizados contra os jesuítas foram se estendendo

\footnotetext{
${ }^{8}$ Essa petição conseguiu reunir 7.403 assinaturas, enquanto uma contrapetição iniciada pelo jornal legitimista A Nação em favor da permanência das religiosas conseguiu juntar 30.226. Cf. Vítor Neto, O Estado, a Igreja e a sociedade em Portugal (1832-1911), Lisboa, Imprensa Nacional Casa da Moeda, 1998, p. 301.

'Esse regresso das ordens religiosas acelerou-se significativamente durante as décadas seguintes, ao ponto de, em vésperas da República, já existirem no país 31 congregações espalhadas por 164 estabelecimentos. Cf. Ibidem, p. 322. Veja-se também José Eduardo Franco; Luís Machado Abreu; Cristiana Lucas da Silva (orgs.), Para a história das ordens e congregações religiosas em Portugal, na Europa e no Mundo, Lisboa, Paulinas, 2014.

${ }^{10} \mathrm{O}$ u seja, 200 religiosas italianas da Congregação das Irmãs de Santa Doroteia e 400 religiosas austríacas da Congregação das Irmãs Franciscanas Hospitaleiras da Imaculada Conceição. Cf. M. Borges Grainha, A propósito do Caso das Trinas. Os jesuítas e as congregações religiosas em Portugal nos últimos trinta anos, Porto, Typographia da Empresa Literária e Typográfica, 1891, p. 25-26.
} 
às comunidades religiosas em geral: celibato, clausura, confissão auricular passaram a ser vistos como atavismos pérfidos dos quais urgia libertar qualquer sociedade que desejasse seguir o caminho do aperfeiçoamento moral e cívico. ${ }^{11}$

Os governos liberais ambicionavam uma
subjugação das estruturas eclesiásticas ao poder
político de modo a colocar o aparelho religioso
ao serviço da nova causa nacional

Em junho de 1891, a morte de uma menina órfã de 14 anos no Convento das Trinas, em Lisboa, fez eclodir uma nova bolha anticlerical. Sara Pereira Pinto de Matos havia sido entregue com sua irmã aos cuidados das freiras Hospitaleiras do Convento das Trinas no ano anterior. Na sequência de alguns dias de indisposição, Sara faleceu subitamente, sem nunca ter chegado a ser vista por um médico. A partir de suposições lançadas pelos resultados da autópsia, a imprensa republicana lançou de imediato a suspeita de que Sara poderia ter sido violada por um padre e depois envenenada, com a conivência das freiras, para abafar o escândalo. Os exames toxicológicos confirmaram a hipótese de envenenamento e uma freira confessou ter equivocadamente administrado à menina um produto que julgava ser um purgante, mas que acabou por se revelar mortífero. A freira foi condenada a uma pena correcional por homicídio involuntário. ${ }^{12}$ Sara foi alçada a mártir da perversidade clerical. Dessa vez, o caso foi mais além da polêmica sobre a existência e as condições de funcionamento das ordens religiosas no país, incidindo sobretudo numa campanha mais generalizada sobre os efeitos perniciosos do elemento clerical na sociedade. À semelhança do Caso das Irmãs da Caridade, o Caso Sara de Matos captou a atenção nacional graças ao empenho da imprensa. Mas, diferentemente do que se havia passado em finais da década de 1850, em 1891, o Caso Sara de Matos contou adicionalmente com a militância anticlerical e protolaicista de um republicanismo, em plena campanha contra o ultimato inglês, a dar os primeiros passos rumo a uma massificação da sua mensagem. O jornal $O$ Século fez uma subscrição para se erguer um mausoléu em homenagem a Sara. Em 1896, a cerimônia de trasladação do corpo e de inauguração do

"Cf. Luís Machado de Abreu, "O discurso do anticlericalismo português (1850-1926)", Brotéria, vol. 160, n. 2 , 2004, p. 161-188. Sobre o mesmo tema, veja-se também Idem (org.), Colóquio anticlericalismo português: história e discurso, Aveiro, Universidade de Aveiro; Centro de Línguas e Culturas, 2001.

${ }^{12}$ Cf. Abílio Maia, A Irmã Collecta. Traços biográficos. A propósito do Caso das Trinas, Braga, Typographia Sá Pereira, 1892, e Eduardo Burnay, "O Caso Sara de Matos (1891)", Archivos do Instituto de Medicina Legal de Lisboa, vol. I, n. 4, 1913. 
monumento funerário contou com a presença de quase vinte mil pessoas e, durante vários anos, fizeram-se romagens cívicas ao local, transformandose a campa da menina envenenada num local de culto laico.

É importante não perder de vista que o trajeto dessa mobilização anticlerical acompanhou, de forma indissociável, o percurso de desenvolvimento coetâneo do livre-pensamento em Portugal, cujas reivindicações incluíam, entre outras, a separação da Igreja do Estado, a escola laica, o registro e o casamento civil, bem como a separação da família da Igreja. Apesar de remontar a 1876 a fundação da Associação Promotora do Registo Civil e a 1882 a da Associação do Livre-Pensamento, foi só a partir da década de 1890 que o movimento começou efetivamente a ganhar dimensão, em parte também devido ao fato de ter sido apadrinhado por outras militâncias, como a socialista ou a maçônica. ${ }^{13} \mathrm{Na}$ sua forma mais elitista (lojas maçônicas e associações de livre-pensamento) ou popular (círios civis ou associações promotoras do registro civil), o livre-pensamento integrou o braço organizado de uma militância laica da qual o anticlericalismo popular constituiu a face mais espontânea. Com efeito, foi na virada do século XIX para o XX que se formou uma coalizão de interesses negativa - maçônica, carbonária, republicana - forjada na militância anticlerical e decidida a não transigir no combate uno à questão de regime e à questão religiosa. ${ }^{14}$

\section{O Caso Calmon (1899-1901)}

Em 1901, uma nova polêmica criada em torno da vocação religiosa da filha do cônsul brasileiro na cidade do Porto conduziu a um dos momentos de maior efervescência anticlerical no país. Rosa Calmon, brasileira, era uma mulher solteira de 32 anos que vivia com os pais no Porto, onde o pai, José Calmon, exercia há quase uma década o cargo de cônsul do Brasil. Numa manhã de domingo do mês fevereiro de 1901, deu-se um esdrúxulo alvoroço à saída da missa na Igreja da Trindade envolvendo pai e filha: Rosa, agarrada a um gradeamento lateral da igreja e abraçada pela mãe em lágrimas, recusava-se a acompanhar os pais. De bengala no ar, o pai clamava que o acudissem, que acudissem o cônsul do Brasil, que lhe raptavam a filha. Um jornalista do Diário da Tarde, estando ali de passagem, foi em auxílio do amigo cônsul, tentando despegar a filha das grades e encaminhá-la até à carruagem da família. Um polícia à paisana deu proteção a este último, acabando por acompanhar a família Calmon de regresso à casa. Como pano de fundo, houve muita vozearia - "tirano", "pai infame", "ladrões" - , gritos e ameaças das várias pessoas que se foram juntando à confusão.

${ }^{13} \mathrm{Cf}$. Fernando Catroga, "A Maçonaria, as congregações e a questão religiosa (séculos XIX e XX)", In: José Eduardo Franco; Luís Machado de Abreu (orgs.), Ordens e congregações religiosas no contexto da I República, Lisboa, Gradiva, 2010, p. 91-108.

${ }^{14} \mathrm{Cf}$. Idem, O republicanismo em Portugal. Da formação ao 5 de outubro de 1910, Lisboa, Editorial Notícias, 2000, p. 88-91. 
Mas o Caso Calmon não começara em fevereiro de 1901 no aparatoso "rapto" da Trindade; era velho pelo menos de dois anos e já havia servido para distinguir alguns contornos mais ou menos sutis da questão religiosa em Portugal. ${ }^{15}$

A vontade de seguir a vida religiosa manifestada por Rosa e contrariada por seus pais era um drama doméstico que, há vários anos, se desenrolava no seio da família do cônsul brasileiro no Porto. Como durante o ano de 1899 as demonstrações da dedicação religiosa de Rosa fossem mais frequentes e esta tivesse se tornado mais obstinada em desafiar a proibição dos pais, José Calmon obrigou a filha a submeter-se ao exame do médico psiquiatra Júlio de Matos, que lhe atestou uma loucura histérica e recomendou que fosse mantida sob observação.

\section{A vontade de seguir a vida religiosa manifestada por Rosa e contrariada por seus pais era um drama doméstico que, há vários anos, se desenrolava no seio da família do cônsul brasileiro no Porto}

Cativa da sua própria família e sabendo-se num país estrangeiro onde a opinião pública tinha pouca simpatia pela sua causa, Rosa decidiu apelar ao superior hierárquico do pai e representante máximo do seu país em território português: em finais de setembro desse mesmo ano de 1899, escreveu uma carta ao chefe da legação brasileira em Lisboa, Júlio de Melo e Alvim, expondo-lhe a sua dramática situação. A carta revela uma mulher na posse das suas faculdades, coerente com suas opções, mas, acima de tudo, cansada e indignada com a situação de desconfiança e vigilância em que vive. Rosa diz-se refém num cárcere privado e pede ao ministro que lhe dê proteção e se solidarize com o seu intuito de abandonar a casa dos pais para ir recolher-se num convento em Lisboa. Num post scriptum, já datado do mês de outubro, queixa-se que o "seu martírio" piorou nos últimos dias, pois passou a ter agentes policiais a guardá-la à porta de casa. Pelo seu caráter historiograficamente inédito e por se tratar de uma das raras, senão mesmo única, expressões da voz de Rosa que subsistiu até nossos dias, vale a pena transcrever a carta na sua totalidade: ${ }^{16}$

\footnotetext{
${ }^{15} \mathrm{Na}$ historiografia contemporânea, o caso foi objeto das seguintes reflexões: Maria Rita Garnel, "O Caso Rosa Calmon: género, discurso médico e opinião pública”, In: Zília Osório de Castro; João Esteves, Falar de mulheres: história e historiografia, Lisboa, Livros Horizonte, 2008, p. 71-87 e, da mesma autora, "Rosa Maria Calmon da Gama”, In: Zília Osório de Castro; João Esteves (dirs.), Dicionário no feminino - séculos XIX e XX, Lisboa, Livros Horizonte, 2005, p. 350-354; Jesué Pinharanda Gomes, O rapto da Rosa: o Caso Calmon, Porto, Separata de O Tripeiro, 2001; e Isabel Corrêa da Silva, Espelho fraterno: o Brasil e o republicanismo português na transição para o século XX, Lisboa, Divina Comédia, 2012, p. 194-232.

${ }^{16}$ Essa carta foi, alguns meses mais tarde, publicada no jornal católico Alliança, do Porto, cujos exemplares são hoje muito difíceis de encontrar, o que ajuda a compreender porque a já escassa literatura sobre o Caso Calmon nunca fez uso dela [Cópia de 9 de junho de 1900], Arquivo Histórico do Itamaraty/Ministério das Relações Exteriores (AHI/MRE), Missões Diplomáticas Brasileiras, Lisboa, Ofícios, cx. 214-3-10 (1901).
} 
Porto, 25 de Setembro de 1899

Cumprimentando a V. Exa. e à sua Exma. família peço-lhe desculpar-me vir incomoda-lo com estas linhas que resolvi escrever-lhe para tratar de um assunto muito sério do qual depende toda a minha felicidade. O que animou-me a isso foi tudo o que tenho sabido a respeito de V. Exa. que pelo seu nome, pela sua posição e pelos seus sentimentos julgo, mais que ninguém, competente para o que desejo pedir-lhe. Creio que não ignora o imenso desejo que tenho de seguir a vida religiosa assim como a grande oposição que fazem a isso os meus pais. Provavelmente sabe também que eles dizem ser essa a minha ideia devido a uma loucura histérica, ou outro qualquer incômodo nervoso, e que o mesmo, pouco mais ou menos, disseram dois médicos a quem consultaram dando-lhes um deles um atestado afirmando isso! Mas nada disso faz-me medo porque a verdade prevalece sempre e ninguém pode dizer que o meu modo de proceder seja de uma pessoa histérica ou fanática. Graças a Deus sempre estive, como estou, em perfeito estado de razão, a minha resolução só foi tomada depois de pensar muito e de pesar todas as coisas e para que V. Exa. conheça toda a verdade e possa formar de seu juízo sobre tudo isso, vou contar-lhe muito resumidamente a minha história. Fui criada e educada sem quase nenhuma educação religiosa e acostumada desde muito pequena a frequentar os teatros e outros divertimentos dos quais gostava como era natural naquela idade e mesmo porque não conhecendo senão essas coisas do mundo. Na idade de quase 24 anos, depois de ter ouvido alguns sermões e práticas que fizeram-me entrar no conhecimento da nossa santa religião, resolvi seguir os bons exemplos e conselhos de algumas pessoas indo confessar-me pela primeira vez na minha vida e fazendo a minha $1^{\text {a }}$ comunhão. Tudo isto foi ainda no Brasil, poucos meses antes de partirmos para cá, e tudo feito sem o Papai saber pois que ele nem admitia que falássemos em nos confessar quanto mais em o fazer! Continuei a frequentar os sacramentos e a estudar diariamente a doutrina, a ler bons livros e a ouvir com mais atenção os sermões e as práticas, e à medida que fui instruindo-me na religião, pela qual senti-me logo atraída o mais possível, fui-me aborrecendo de todos os prazeres do mundo a tal ponto que ultimamente não pude de todo aturá-los mais.

Por esse e outros motivos comecei a conhecer que a minha vocação era toda para a vida religiosa e que se antes não a sentia era pela ignorância em que vivia, pois como poderia eu gostar de uma coisa que não conhecia?! Houve um tempo em que a Mamãe deixou-me sair só muitas vezes e eu aproveitei-me dessa liberdade para frequentar alguns colégios de religiosas com as quais conversei muitas e muitas vezes certificando-me cada vez mais de que era mesmo aquela a minha vocação. Comecei a pensar muito nisso e a pedir a Deus luzes e graça para bem conhecer a Sua vontade. Três anos a seguir fiz os exercícios espirituais e não só naqueles dias como depois todo o ano continuava a pensar sempre no mesmo ponto. No fim desse tempo tendo a certeza de que, com a graça de Nosso Senhor, nada mais me faria mudar, que a minha resolução estava tomada para sempre, pensei em fazer conhecer a meus pais as minhas ideias e obter o seu consentimento para seguir a minha vocação, mas antes 
disso quis dar todos os passos, isto é, certificar-me de ser ou não recebida nas minhas condições, sem poder levar dote nem mesmo um enxoval, e graças a Nosso Senhor, tudo consegui logo, sem a mínima dificuldade, recebem-me à hora que eu quiser sem nada levar-lhe senão a minha boa vontade e o desejo imenso que tenho de dedicar-me ao serviço de Deus e só viver para Ele.

Ainda esperei alguns meses para dar tempo a chegar a minha tia Carapebus que vinha passar alguns dias conosco pois como ela era muito religiosa e muito boa imaginei que pudesse ajudar-me a conseguir o consentimento de meus pais, mas antes do dia da sua chegada o Papai soube das minhas ideias por uma pessoa estranha e eu então não esperei mais nada e disse-lhes tudo. Eles fizeram logo a maior oposição possível e entre outras coisas cortaram relações com as famílias das minhas melhores amigas que não tiveram a mínima culpa em nada pois que tudo partiu só de mim, ou melhor, de Deus. Tentaram todos os meios até o de quererem convencer-me de que eu estava doida, que tudo isso era devido ao histerismo e que era preciso que eu me convencesse disso para fazer um esforço sobre mim e ficar boa desse estado. Afinal vendo que nada me fazia mudar e que eu sabia perfeitamente que com quase 30 anos de idade estava no meu direito de seguir o estado de vida que quisesse, lembraram chamar os tais médicos e conseguiram que um deles lhes desse o atestado de que já falei, provavelmente para terem essa prova a seu favor no caso de eu tentar ir mesmo contra a vontade deles. Enfim, tenho sofrido coisas que só Deus sabe, a minha vida nestes dois anos tem sido um verdadeiro martírio, com 31 anos feitos vejo-me presa e vigiada como uma menina de 14 ou 15 (e quantas nessa idade tem mais liberdade do que eu com 31!).

Bem sei que é o amor (embora um amor muito mal entendido) que os cega a ponto de fazerem-me tantas injustiças que lhes perdoo com todo o coração pois que estimo muito os meus pais e por isso tenho esperado todo esse tempo a ver se conseguia que me dessem o seu consentimento e a sua bênção antes de partir, o que seria para mim o cúmulo da felicidade, mas infelizmente vejo que a minha paciência, submissão e condescendência nada têm conseguido. Sinto-me infeliz o mais possível e não posso mais sofrer esse martírio, por isso venho pedir a V. Exa. o enorme favor de falar ao Papai dizendo-lhe que sabe quanto me sinto infeliz no mundo e quanto desejo seguir a vida religiosa. Faça-lhe ver que se eu me casasse, como eles tanto desejam, não ficaria também a morar em casa deles, que se me casasse, por exemplo, com um diplomata teria de separar-me [deles] como a mamãe está separada da sua família [e o meu irmão] é que está no Brasil, de todos nós, [dentro do] convento ele poderá achar-me quando quiser ir visitar-me e ter notícias pelas cartas. Explique-lhe que o passo que desejo dar nada desonra a minha família, ao contrário, quantas pessoas muito distintas e até [princesas] fizeram-se freiras e não se pode dizer que elas se rebaixassem ou aos seus. Conte-lhe que tem também uma prima freira e que por isso não deixa ela de ser muito considerada por todos assim como toda a sua família. Digalhe afinal que sendo ele tão bom Pai devia estar pronto a fazer esse sacrifício, embora contrariado para fazer feliz uma filha que nunca 
o poderá ser de outra maneira. Mas desculpe-me estar a lembrar tudo isso sabendo V. Exa. mil vezes melhor do que eu o que deverá dizer-lhe. Confio tudo à sua inteligência e ao seu bom coração, o que só lhe peço é que empregue todos os esforços para obter esse tão desejado consentimento fazendo tudo por tocar-lhe o coração que é muito terno, muito bom. Mas se depois de tudo isso ele continuar a não querer ceder, peço então a V. Exa. a sua competente proteção como Ministro Brasileiro pedindo-lhe que empregue os meios necessários para que me seja dada a liberdade a que tenho direito pois que de todo não posso mais continuar nesta vida de martírio e estou mais que resolvida a seguir já a minha vocação. Será isso uma enorme felicidade para mim e um sossego para a minha família pois como, com a Graça de Deus, nada mais me fará mudar de resolução eu só lhes poderei servir de tormento enquanto eu estiver privando-os de se divertirem, porque não querem ir sem que eu os acompanhe, e atormentando-os sempre em pedir que me deixem seguir a minha vocação.

Espero, ou antes, tenho quase a certeza que V. Exa. fará tudo o que acabo de pedir-lhe e que muito breve lhe deverei a minha felicidade! Peço-lhe ainda mais um favor muito grande que é o de levar-me consigo para Lisboa quando para lá voltar com sua Exa. família e lá direi então para que ordem desejo entrar. Pode dizer ao Papai (como coisa sua) que isso será muito conveniente mesmo para ele pois que talvez com a distração da viagem, a companhia da sua filha Iréne, eu talvez até mude de ideias pois talvez com essa esperança ele deixe-me ir mais facilmente. Desde já agradeço-lhe mil vezes muito reconhecida e subscrevo-me, muito atenta e veneranda e muito obrigada,

\section{Rosa Maria Calmon da Gama}

P.S. a 4 de Outubro de 1899. Depois desta carta escrita, esperando para enviá-la no regresso de V. Exa. ao Porto aumentou-se muito o meu martírio, já não me respeitam e até me maltratam, conservam-me agora presa com polícias à porta dia e noite e estes acompanham-me quando saio de casa, embora eu esteja acompanhada pela Mamãe, tratam-me enfim como se eu fosse uma louca. Isto é superior às forças humanas, e como a verdade é que estou em meu perfeito juízo e não quero faltar aos deveres de filha, e desejo andar com muita prudência, não queria, por causa da posição de Papai, que nenhuma pessoa estrangeira tomasse conhecimento destes fatos, mas se de todo não puder mais, ouço falar com tal respeito do Sr. Bispo do Porto que é possível que lhe peça a sua proteção, o que só forçada farei, e isso pode dar-se sem mesmo eu ter recebido a resposta de V. Exa. para quem de novo apelo como amigo de meu pai, como representante do meu país e como cavalheiro e homem de bem. Se por acaso V. Exa. tiver algum recado ou alguma carta a mandar-me peço-lhe o favor de não o fazer de maneira nenhuma pelo correio porque seria a carta de certo aberta e lida por alguém da família, por isso se tiver alguma resposta será melhor mandá-la por uma das suas Exmas. filhas pedindo-lhe que ma entregue de maneira que ninguém veja ou perceba isso. 
Desesperada, e sem resposta que lhe valesse, poucos meses depois, Rosa intentou uma fuga, mas acabou por ser apanhada na estação ferroviária de Alfarelos, perto do Porto, por agentes da polícia que a obrigaram a retornar a casa. Daí em diante, a presença policial à porta da residência do cônsul tornouse permanente e Rosa decidiu interpelar publicamente o governador civil do Porto, instando-o a tomar providências contra a ilegalidade da situação a que estava a ser sujeita. ${ }^{17}$ Simultaneamente, temendo que Rosa intentasse nova evasão, o pai abriu um processo de interdição por demência da filha. Foi a partir desse momento que uma questão até então limitada ao foro doméstico entrou na esfera dos tribunais e se transformou numa polêmica que, durante mais de um ano, apaixonou e dividiu opiniões. ${ }^{18}$

Dois médicos, Joaquim Urbano da Costa (subdelegado de saúde do Porto) e Júlio de Matos (diretor do Hospital de Alienados Conde de Ferreira), foram chamados pelo juiz da $4^{\text {a }}$ Vara Cível da Comarca do Porto a pronunciarem-se sobre a possibilidade de fundamentação clínica da interdição que José Calmon exercia sobre a sua filha. $\mathrm{O}$ primeiro considerou que Rosa estava no funcionamento regular das suas faculdades mentais. Júlio de Matos, por seu lado, solidarizou-se com o cônsul brasileiro e, sustentado nas corroborações que, à distância e sem nunca terem consultado Rosa, outros médicos alienistas nacionais e estrangeiros deram ao seu diagnóstico, firmou, a 16 de maio de 1900, o seguinte parecer:

[...] Degenerescência física hereditária, de que são síndromas a histeria constitucional e a loucura lúcida (variedade afetiva). Constatando que a paixão religiosa produziu na arguida, eminentemente sugestionável, um estreitamento do campo de consciência, incompatível com o livre exercício da vontade e escolha de motivos de ação, voto por que ela seja interdita. ${ }^{19}$

Nesse impasse, foi nomeada uma primeira junta de três médicos que se recusou a pronunciar sobre o caso, alegando incompetência na matéria de doenças alienistas. Depois de muita controvérsia, o juiz pediu a nomeação de uma segunda junta trina, da qual dois médicos decidiram em favor da sanidade mental de Rosa e um encontrou-lhe uma degenerescência psíquica. Ao cabo de vários meses, inconclusivamente a passar de mão em mão entre quase uma dezena de médicos, o processo acabou terminando por desistência da ação por parte de José Calmon.

\footnotetext{
${ }^{7}$ Ofício de Júlio de Melo e Alvim ao ministro das Relações Exteriores brasileiro, 3 de maio de 1900, AHI/MRE, Missões Diplomáticas Brasileiras, Lisboa. Ofícios, cx. 214-3-9 (1900).

${ }^{18} \mathrm{~A}$ questão Calmon abarcou dois processos distintos: o primeiro, tendo em vista a interdição por demência de Rosa, foi iniciado por José Calmon, decorreu pela 4a Vara Cível da Comarca do Porto e terminou por desistência da ação da parte de José Calmon. O segundo processo, iniciado por António Ferreira Alves Pacheco contra José Calmon por alegadamente manter a filha em cárcere privado, decorreu pelo $2^{\circ}$ Distrito Criminal do Porto e foi arquivado por deliberação do delegado do Ministério Público e por sentença corroborativa do juiz Margarido Pacheco, a 10 de março de 1901. Cf. Promoção do delegado do 20 Distrito Criminal do Porto (27 de fevereiro de 1901) e Sentença do juiz Margarido Pacheco (10 de março de 1901), transcritas em "Uma promoção honrosa", O Século, 8 de março de 1901, p. 4, e Bernardo Lucas, Aspecto jurídico do Caso Calmon, Porto, Typ. Arthur Souza e Irmão, 1901, p. 7-38.

${ }^{19}$ Parecer de 16 de maio de 1900 apud Júlio de Matos, A Questão Calmon. Reflexões sobre um caso médicolegal, Porto, Livraria Moreira, 1900, p. 16.
} 
Mas enquanto juízes e médicos tentavam chegar a um acordo sobre as faculdades mentais de Rosa, o Caso Calmon saltou dos tribunais para a rua e daí para as chancelarias e para o Parlamento. Como o cônsul brasileiro continuasse a manter a filha sob vigilância policial, embora não tenha havido qualquer deliberação judicial nesse sentido, alguns jornais católicos do Porto, como O Norte e A Palavra, levantaram-se em indignação contra a violência e arbitrariedade do cônsul e, nessa senda, foi aberta uma ação judicial contra José Calmon.

"Tenho sofrido coisas que só Deus sabe,
a minha vida nestes dois anos tem sido um
verdadeiro martírio, com 31 anos feitos vejo-me
presa e vigiada como uma menina de 14 ou 15"

Ecos dessas notícias chegaram rapidamente às Cortes. Na sessão de 27 de abril de 1900 da Câmara dos Pares, o conde de Bertiandos questionou o governo sobre as informações chegadas do Porto as quais pareciam sugerir que o cônsul brasileiro daquela cidade cometia o crime de manter a filha, maior de idade, em cárcere privado e que a situação era tolerada pelas autoridades para evitar melindres diplomáticos. ${ }^{20} \mathrm{O}$ governo respondeu evasivamente e a questão não teve mais seguimento. Mas o cônsul brasileiro contava, de fato, com a solidariedade das autoridades portuenses que, disponibilizando um policial para impedir Rosa de sair de casa, agiam à revelia de qualquer decisão judicial. Numa carta desse mês para o seu chefe em Lisboa, o cônsul confessava que, até o momento, nenhuma das autoridades do Porto lhe haviam faltado "com a sua benevolência e proteção". ${ }^{21}$ Mas José Calmon queria mais que a benevolência das autoridades locais. Queria garantir também a simpatia das autoridades governamentais para, no caso de se ausentar do país, ter a certeza de não ser impedido de levar a filha, mesmo contra a vontade desta.

Tratava-se, na verdade, de um conflito de quadros legais. Pela lei portuguesa, a coação do cônsul era de fato ilegal, uma vez que Rosa era maior de idade e tinha todo o direito de decidir não acompanhar o pai. Mas, como diplomata, José Calmon alegava não ter obrigação de se submeter à lei do país e ser prerrogativa do seu poder paternal decidir sobre o destino da filha, que, à luz das antigas Ordenações do Reino, ainda em vigor no Brasil, mesmo maior de idade, continuava sob sua tutela enquanto filho-família. Na acesa correspondência trocada na altura entre o cônsul e o ministro plenipotenciário brasileiro em

${ }^{20}$ Debates da Câmara dos Dignos Pares do Reino (DCDPR), 8 a Sessão, 11 de fevereiro de 1901, p. 76-77. O conde de Bertiandos já havia levado a questão às Cortes quase um ano antes, pouco após a primeira tentativa frustrada de fuga de Rosa, em março de 1901. Cf. DCDPR, 23 a Sessão, 27 de abril de 1900, p. 159.

${ }^{21}$ Carta de José Calmon a Júlio de Melo e Alvim, 11 de abril de 1900, AHI/MRE, Missões Diplomáticas Brasileiras, Lisboa. Ofícios, cx. 214-3-9 (1900). 
Lisboa, o que mais desassossegava José Calmon era o receio de que a campanha levantada na opinião pública pelos meios católicos em favor das pretensões de Rosa pudesse levar o governo português a hesitar e pôr em causa as suas garantias diplomáticas. Pedia, por isso, ao ministro brasileiro em Lisboa que intercedesse em seu favor junto do governo português e que, em último caso, solicitasse a intervenção do presidente da República do Brasil. O ministro brasileiro em Lisboa, por sua vez, negava-se terminantemente a importunar os seus superiores, insistindo que o assunto era do foro particular e que, na pior das hipóteses, deveria ser tratado nas instâncias civis ou criminais portuguesas, mas nunca pelas chancelarias diplomáticas. A correspondência entre cônsul e ministro brasileiros foi azedando ao longo do ano de 1900, com Calmon constantemente a cobrar a Melo e Alvim o pouco apoio recebido pela legação e com o ministro a mostrar-se cada vez mais mais agastado com as reivindicações e insinuações daquele.

O tom das missivas trocadas com o cônsul no Porto, ou com o ministro das Relações Exteriores do Brasil, dá a entender que Melo e Alvim teria, de fato, mais simpatia pela causa da filha do que pela do pai. Sobretudo dá a entender que se sentia muito incomodado com todas as manifestações de radicalismo anticlerical que, por aquela altura, andavam associadas ao nome do seu país. Em ofício já de agosto de 1901 para seu chefe no Brasil, Alvim queixava-se das muitas maçadas que tinha tido com o Caso Calmon, inclusive com funcionários da própria legação que se haviam juntado à campanha em favor da causa do cônsul do Porto, promovida, segundo suas palavras, por "grupos de jacobinos portugueses e brasileiros".22

Em meados de maio, o jornal Alliança publicou a carta de Rosa a Melo e Alvim e o assunto foi-se mantendo aceso na imprensa portuense, com os jornais a acompanharem os avanços e recuos dos dois processos judiciais contra pai e filha que corriam em paralelo. No fim desse ano, Júlio de Matos publicou em livro o relatório médico-legal que redigira como perito no processo de interdição de Rosa. ${ }^{23}$ Em princípios de 1901, a vida de Rosa Calmon continuava a ser matéria assídua na praça pública. Na sessão do dia 11 de fevereiro da Câmara dos Pares, o conde de Bertiandos voltava a insistir com o governo para que Rosa tivesse a sua liberdade individual legalmente assegurada, pedindo ainda explicações sobre a escandalosa cumplicidade da polícia com a arbitrariedade do cônsul do

\footnotetext{
${ }^{22}$ Um dos secretários do consulado, José de Alencar, decidiu mesmo fazer greve ao trabalho e recusarse a obedecer às ordens do seu chefe. O ministro brasileiro viu-se obrigado a apresentar queixa dele ao ministro das Relações Exteriores brasileiro, referindo-se ao funcionário como fazendo parte de "um grupo de jacobinos portugueses e brasileiros" fiéis à causa do cônsul do Porto. Cf. Ofícios de Júlio de Melo e Alvim ao ministro das Relações Exteriores, agosto de 1901, AHI/MRE, Missões Diplomáticas Brasileiras, Lisboa, Ofícios, cx. 214-3-10 (1901).

${ }^{23} \mathrm{O}$ relatório de Matos é acompanhado pelos pareceres dos oito especialistas - Dallemagne (Bruxelas), Régis (Bordéus), Lombroso (Turim), H. Maudsley (Londres), Schule (Illenau), Magnan (Sant’Anna), Séglas (Bicetre), Morselli (Génova) - que, partindo apenas do relatório de Júlio de Matos e sem nunca terem visto Rosa, corroboraram de forma geral o diagnóstico de demência histérica. Para uma contextualização do caso num panorama mais vasto dos avanços da psiquiatria e das suas consequências e instrumentalizações políticas em Portugal, veja-se António Araújo, Jesuítas e antijesuítas no Portugal republicano, Lisboa, Roma Editora, 2004, p. 125-129, e Ana Leonor Pereira, Darwin em Portugal: filosofia, história, engenharia social (1865-1914), Coimbra, Almedina, 2001, p. 359-434.
} 
Brasil. O presidente do ministério, Hintze Ribeiro, garantiu que as autoridades do Porto não compactuariam com qualquer ação que contrariasse as deliberações do poder judicial. Não obstante, Rosa continuava "protegida" por um agente da polícia. Até que, no dia 17 de fevereiro, à porta da Igreja da Trindade, a situação se precipitou de modo a polarizar ainda mais os dois lados da contenda.

As notícias dos dias seguintes que relatam o sucedido no adro da Igreja da Trindade apresentam tal disparidade na descrição dos acontecimentos que um leitor incauto podia ser levado a concluir que se tratava de dois episódios distintos. Praticamente, o único ponto em comum possível de encontrar entre os relatos das folhas conservadoras e das radicais é a afirmação de que Rosa há muito vivia contrariada na casa de seus pais, que a impediam de seguir a vocação religiosa. Daí em diante, a história bifurca-se sem remissão. O Correio Nacional, jornal liberal conservador, relata o seguinte cenário: à saída da Igreja da Trindade, a senhora Rosa Calmon comunicou à sua mãe que não regressaria mais à casa e que tencionava aceitar o alojamento de uma senhora amiga, D. Maria Almeida Garrett, para, de seguida, cumprir a sua vontade de entrar para um convento. Ao aperceber-se da declaração da filha, o cônsul brasileiro entrou em descompensação irada, fazendo um grande alvoroço e ameaçando a filha a bengaladas e de morte quem se aproximasse desta, ao mesmo tempo em que a puxava para junto de si. Resistindo à pressão do pai, Rosa agarrou-se às grades laterais da igreja. Contando com a proteção de um policial à paisana e com a ajuda de um amigo, o cônsul do Brasil conseguiu arrastar a filha até à sua carruagem. No adro da igreja, ficou uma assistência perplexa perante tal ato de "selvajaria" e algumas "nódoas de sangue" a manchar a cantaria por debaixo dos ferros de onde Rosa fora arrancada. ${ }^{24}$

O mesmo episódio é contado por O Século, jornal republicano moderado, nos seguintes moldes: à saída da Igreja da Trindade, um grupo de elementos reacionários tentou raptar a filha do cônsul do Brasil para enclausurá-la num convento. O pai cresceu em defesa da filha, defrontando-se com um bando de clericais que lhe erguiam os punhos enquanto ele os afastava de bengala em riste, ao mesmo tempo em que clamava pela ajuda do povo contra os ladrões que lhe raptavam a menina. Nisso, um policial à paisana tentou tomar o controle da situação e criar uma clareira para proteger a família Calmon dos presumíveis raptores, deixando que o jornalista do Diário da Tarde se aproximasse de Rosa, "brandamente" lhe desprendesse as mãos do gradeamento onde ela se tinha agarrado e, rompendo "com serena energia" o grupo que a rodeava, a encaminhasse, de braço dado, até à carruagem dos pais. $\mathrm{O}$ mesmo jornal conta ainda que a menina acompanhou o jornalista "docilmente e sem resistência de maior", que o sangue lhe havia rebentado "em pequeníssima quantidade" devido ao fato de "ter as mãos inchadas e cheias de cieiro por causa do frio" e que o "atentado" fora combinado previamente entre a própria raptada e o seu confessor. ${ }^{25}$

24“Sem Comentários”, Correio Nacional, 18 de fevereiro de 1901, p. 1.

25“O Caso Calmon”, O Século, 21 de fevereiro de 1901, p. 1-2; “O Século no Porto”, Ibidem, 22 de fevereiro de 1901, p. 1-2. 
Independentemente da disparidade das versões, o episódio desencadeou uma verdadeira fúria anticlerical, que, iniciando-se logo de imediato na cidade do Porto, rapidamente se estendeu a Lisboa e a outros pontos do país. No domingo seguinte, uma manifestação de solidariedade esperava o cônsul brasileiro à saída da Igreja da Trindade. Como nenhum Calmon tivesse comparecido à missa, o grupo de manifestantes dirigiu-se, então, à residência da família, onde finalmente vislumbrou o cônsul, que veio à janela agradecer a demonstração de apoio e dar vivas ao "libérrimo povo do Porto" sobre quem lançou pétalas de flores. Já compacta, a massa de populares regressou depois ao Largo da Trindade para vaiar os padres e queimar exemplares do jornal católico A Palavra. A polícia interveio e tentou dispersar o ajuntamento; fizeram-se alguns feridos e presos. Durante o resto do dia, magotes de pessoas passearam-se pelas ruas do Porto dando vivas à porta dos jornais liberais e gritando morras aos jesuítas, enquanto escapavam às pranchadas da polícia. ${ }^{26} \mathrm{~A}$ onda anticlerical, que havia começado no dia anterior com o apedrejamento das instalações do jornal A Palavra, ${ }^{27}$ estendeu-se a outros focos clericais do Porto, tendo sido apedrejados o Recolhimento das Doroteias e a Associação Católica. Cerca de cinco mil pessoas reuniram-se à porta da casa de José Guimarães Pestana, chefe reconhecido do partido ultramontano e absolutista portuense, destruindo janelas e grades de ferro à pedrada, arrancando e incendiando cortinados. Vários padres foram perseguidos na rua debaixo de ameaças "Morra que é jesuíta; Apanha que é da seita!”. As autoridades municipais foram obrigadas a manter as principais casas religiosas da cidade sob a proteção de um contingente policial. ${ }^{28}$

Focos de manifestações clericais espalharam-se por todo o país, do Porto a Lisboa, mas também em cidades de província, sobretudo nas que tinham alguns pequenos núcleos republicanos mais enraizados. No dia primeiro de março, os estudantes do Politécnico, do Instituto Comercial e da Escola Médica improvisaram uma procissão satírica, que calcorreou algumas ruas do Porto, erguendo um estandarte com um fantoche caricatural de um ultramontano "em roupeta estranha e liberrimamente enfeitado". Em revanche, nessa noite, "rebentaram duas bombitas de vintém" perto do Instituto Comercial. ${ }^{29}$ Nesse mesmo dia, em resposta ao descontrolo da rua, o governo-civil do Porto publicou um edital impedindo a circulação de jornais ou qualquer tipo de impressos que incitassem a qualquer ato perturbador da ordem ou atentatório dos direitos individuais e proibindo a exibição de quaisquer "desenhos ou imagens ofensivas do decoro de funcionários, corporações ou particulares". ${ }^{30}$ Como seria de esperar, essas ordens de censura causaram indignação entre os portuenses. A Associação dos Jornalistas e Homens de Letras do Porto redigiu um protesto coletivo ao

26"O Caso Calmon", O Século, 25 de fevereiro de 1901, p. 2, e "Um caso de sensação", O Primeiro de Janeiro, 28 de fevereiro de 1901, p. 1 e 10 de março de 1901, p. 2.

27"O Caso Calmon: tumultos no Porto", op cit., 24 de fevereiro de 1901, p. 4

${ }^{28} /$ bidem, 28 de fevereiro de 1901, p. 1.

${ }^{29} \mathrm{O}$ Primeiro de Janeiro, 10 de março de 1901, p. 2

30"Edital de 10 de março de 1901" apud Diário da Câmara dos Senhores Deputados, sessão de 5 de março de 1901, p. 2 
Parlamento, convidando o deputado da oposição, José Maria de Alpoim, para relator. ${ }^{31}$ Nos últimos dias de fevereiro e início de março, o assunto tomou conta dos debates parlamentares. O Partido Progressista não perdeu a oportunidade para denunciar a prepotência e o despotismo das autoridades na resposta às perturbações da ordem pública. Mas, sobretudo, a oposição conseguiu fazer do caso uma arma política eficaz para confrontar o governo com um dos pontos mais melindrosos da questão religiosa nacional e que se prendia à situação de ilegalidade em que se encontravam as corporações religiosas, oficialmente proibidas por lei desde 1834.

\section{O episódio desencadeou uma verdadeira fúria anticlerical, que, iniciando-se logo de imediato na cidade do Porto, rapidamente se estendeu a Lisboa e a outros pontos do país}

Pelas principais cidades do país, a situação foi assumindo feições tumultuosas, com a população na rua praguejando contra os padres e os jornais pregando contra a ilicitude das ordens religiosas. Os protestos da opinião pública e a pressão parlamentar intensificaram-se de tal modo que o governo foi obrigado a tomar medidas: no dia 10 de março, emitiu um decreto exigindo aos governadores civis que inquirissem dentro das suas áreas de jurisdição sobre a existência de "instituições ou ordens religiosas de qualquer denominação, instituto ou regra" destinadas à vida monástica, bem como de "estabelecimentos de ensino, propaganda, beneficência ou caridade dirigidos ou administrados por congregações religiosas" e se nalguma dessas casas se dava a "admissão de ordens sacras a noviciados para a vida monástica". ${ }^{32}$

Os resultados do inquérito revelaram o que há muito se sabia: havia espalhados por todo o país vários conventos e mosteiros em plena liberdade e autonomia. A publicidade dessa situação obrigou o governo a tomar uma atitude em conformidade com a moldura legal em vigor: por decreto de $18 \mathrm{de}$ abril de 1901, mandaram-se encerrar as casas religiosas exclusivamente dedicadas à vida monástica e estipularam-se os requisitos e princípios reguladores para a futura instalação de associações de carácter religioso no país, que teriam obrigatoriamente de se dedicar à "beneficência, à caridade, ao ensino ou às missões ultramarinas". O diploma reconhecia que se haviam subrepticiamente introduzido no país muitas associações religiosas cuja existência era conhecida

\footnotetext{
31"Discurso de José Maria de Alpoim", Diário da Câmara dos Senhores Deputados, sessão de 5 de março de 1901, p. 2-4.

32“Decreto de lei de 10 de março de 1901”, Colecção Oficial de Legislação Portuguesa. Ano de 1901 (1902), p. 61. Veja-se sobre o assunto Ruy Ennes Ulrich, Estudo sobre a condição legal das ordens e congregações religiosas em Portugal, Coimbra, Imprensa da Universidade, 1905, p. 103-125.
} 
de fato, mas, por serem desconhecidas oficialmente pelo Estado, não estavam sujeitas a qualquer tipo de fiscalização. Admitia ainda que era impossível "eliminar de chofre" tudo o que se encontrara, não só porque aí "havia muito de altruísta e de bom", mas também porque se deveria evitar o perigo de "lançar na sociedade uma funda perturbação, a que os meios administrativos e os recursos do tesouro dificilmente poderiam acudir de pronto". Feitas as contas, abriam-se novamente as portas à entrada das ordens religiosas em Portugal, desde que enroupadas em associações, embora legalmente proibidas de ter clausura ou votos religiosos previstos nos seus estatutos. ${ }^{33}$

O decreto 18 de abril conseguiu a proeza de reunir o descontentamento de todos: dos meios católicos, ao corroborar o encerramento coercivo de muitas casas de recolhimento religioso; ${ }^{34}$ dos anticlericais, ao prover de enquadramento legal o status quo de permanência das associações religiosas no país. Entre as reações ao frustrado "rapto" de Rosa Calmon e os ecos da promulgação da lei de 18 de abril, o anticlericalismo esteve ao rubro durante o ano de 1901: manifestações contra os jesuítas e as ordens religiosas sucederam-se a um ritmo quase diário, o escritor Sampaio Bruno propôs a criação de uma União Anti-Jesuítica transversal a todo o arco político e alguma imprensa avançou com a proposta da trasladação dos restos mortais do marquês de Pombal para o panteão do mosteiro dos Jerônimos. ${ }^{35}$

Enquanto o rastilho do Caso Calmon continuava incendiando a questão religiosa país afora, o novelo do drama familiar dos Calmons parecia encaminhar-se para o desenlace. Os magistrados julgaram não haver provas suficientes para pôr em causa a sanidade de Rosa, mas nem tão pouco para condenar o pai pela abusiva coerção que exercia sobre ela. ${ }^{36} \mathrm{O}$ delegado do Ministério Público do $2^{\circ}$ Distrito Criminal do Porto considerou que não havia razões para se falar em cárcere privado e que não podia ser moral, civil ou criminalmente condenável que um pai exercesse "uma certa vigilância sobre os atos de uma filha", mesmo sendo ela maior de idade. Do mesmo modo, acrescentava que ninguém condenaria um pai que tomasse as precauções necessárias para impedir que o seu filho ou filha, independentemente da respectiva maioridade legal, fugisse de casa dos pais "para se afogar" ou "para se prostituir num lupanar".37 Era assim, comparando o convento ao fundo de um poço ou a um prostíbulo, que o representante do Ministério Público mandava arquivar o processo, isentando o cônsul brasileiro de quaisquer culpas e deixando Rosa, adulta e legalmente sã, permanecer sob seu domínio.

\footnotetext{
33"Decreto de lei de 18 de abril de 1901", Colecção Oficial de Legislação Portuguesa. Ano de 1901 (1902), Lisboa, Imprensa Nacional, p. 112-115.

${ }^{34}$ Cf. "Carta do Espiscopado Portuguez a Sua Magestade. De 23 de abril de 1901", assinada pelo cardeal patriarca de Lisboa, arcebispo de Braga, Évora, Portalegre e Algarve, bispo de Viseu, bispo conde, bispo de Lamego, bispo de Bragança, bispo do Porto, A Palavra, 28 de abril de 1901, p. 1.

35“A união anti-jesuítica”, A Voz Pública, 5 de março de 1901, p. 1, e O Século, 26 de março de 1901, p. 1.

${ }^{36} \mathrm{Cf}$. Promoção do delegado do 20 Distrito Criminal do Porto (27 de fevereiro de 1901) e Sentença do juiz Margarido Pacheco (10 de março de 1901), transcritas em "Uma promoção honrosa”, Ibidem, 8 de março de 1901, p. 4, e Bernardo Lucas, Aspecto jurídico do Caso Calmon, Porto, Typ. Arthur Souza e Irmão, 1901, p. 7-38. 37“Uma promoção honrosa”, op cit.
} 
Porque o assunto já ultrapassara há muito as proporções de polêmica familiar ou mesmo local, o governo brasileiro achou por bem agir determinantemente sobre o foco da controvérsia e, em princípios de março, ordenou ao cônsul do Brasil a sua transferência para outro posto. Nas vésperas da partida, José Calmon ainda fez algumas declarações à imprensa portuense dizendo-se "sucumbido" pela ordem do seu Ministério e "profundamente penalizado" pela súbita retirada. Não obstante a mágoa, o cônsul brasileiro abandonou o país nas condições que desejava, ou seja, levando consigo toda a família, incluindo, naturalmente, Rosa. ${ }^{38}$

\section{Era assim, comparando o convento ao fundo de um poço ou a um prostíbulo, que o representante do Ministério Público mandava arquivar o processo}

Entre 1900 e 1901, os Calmons foram uma espécie de termômetro para medir febres anticlericais em Portugal. Mas não só. É verdade que a campanha antijesuítica e anticongreganista mobilizou uma relativa unanimidade das opiniões. Mas o debate público sobre as desventuras de Rosa Calmon incluiu outras questões de menor consenso. $\mathrm{O}$ peso da Ciência e a ascendência do poder intelectual dos médicos na sociedade foram algumas dessas questões. ${ }^{39}$ O conhecimento médico - e o psiquiátrico, em particular - serviu com justeza o paradigma de hegemonização de uma concepção do mundo laica e científica, liberta de outras lealdades que não a da razão. Na introdução do seu relatório publicado ainda em 1900 sobre o Caso Calmon, Júlio de Matos deixou bem clara essa ideia, afirmando:

O convento é como as prisões e os manicómios, um meio de eliminação de muitos degenerados, um instrumento de segregação dos que não podem por inferioridade mental adaptar-se às condições de vida comum, de sorte que, socialmente encarada a questão, permitir à Sr. Rosa a prossecução do seu obsessivo desejo, seria, talvez, um ato de higiene coletiva. ${ }^{40}$

O Caso Calmon só pode compreendido tendo-se presente o sucesso que à época tinha esse tipo de discurso assente numa visão racional e cientificamente padronizada do mundo, onde os desvios deviam ser, de igual modo, científica e racionalmente enquadrados e institucionalizados. A história de Rosa é também exemplificativa de como esse discurso funcionou enquanto mecanismo de

${ }^{38} \mathrm{Cf}$. "O governo brasileiro - pedido de retirada de Calmon", O Século, 27 de fevereiro de 1901, p. 2.

${ }^{39} \mathrm{Cf}$. Rita Garnel, "O poder intelectual dos médicos”, Separata de Revista de História das Ideias, vol. 24, 2003, p. 213-253. Veja-se igualmente Ana Leonor Pereira; João Rui Pita (coords.), Miguel Bombarda e as singularidades de uma época (1851-1910), Coimbra, Imprensa da Universidade, 2006.

40 Júlio de Matos, A Questão Calmon. Reflexões sobre um caso médico-legal, Porto, Livraria Moreira, p. 7. 
poder e controle ao serviço de preconceitos sociais e culturais, projetos políticos e arbítrios individuais. ${ }^{41}$ A situação de Rosa, que a muita gente pareceu uma inadmissível violação das liberdades individuais, foi entendida por uma significativa parte da opinião pública como uma medida de exceção cientificamente legitimada. Sobretudo pela opinião de esquerda, mais ligada a um certo progressismo político e aos meios republicanos. De fato, se entre os jornais monárquicos houve os que apoiaram o pai e os que advogaram a causa da filha, ${ }^{42}$ os jornais republicanos alinharam quase em bloco na defesa do cônsul brasileiro.

$\mathrm{O}$ fato de ter passado para a esfera da Ciência e da Moral um debate que parecia simplesmente destinado ao domínio do Direito (coerção ilegítima das liberdades civis de um indivíduo) é um claro sinal de que, em inícios do século XX, a questão religiosa estava já impregnada de outras problemáticas que iam muito além do tradicional anticlericalismo liberal. Progressivamente encabeçada pelo republicanismo de feição mais radical, a questão religiosa portuguesa passou a ser indissociável de uma fé laica que pulsava no coração de todos aqueles que acreditavam num projeto revolucionário para a regeneração da sociedade portuguesa.

Pela simples leitura das principais folhas republicanas, torna-se evidente como consideraram o Caso Calmon muito além do seu enquadramento legal. A ornamentar a mistificação em torno da "tragédia" do complô jesuítico e da profissão de fé na infalibilidade dos diagnósticos médicos, há toda uma semântica condenatória da "imoralidade" e da "impureza" reveladora de uma mundividência revolucionária, que não só não admite concorrência, como também assenta a sua indefectível legitimidade simultaneamente na certeza da Ciência e na pureza da Moral. Sampaio Bruno, que nunca padeceu dos radicalismos anticlericais de muitos de seus correligionários republicanos, refletindo a posteriori sobre o Caso Calmon, deixou expresso com clareza esse entendimento de uma determinada hierarquia de valores:

Um pai [...] tem o direito, animal, profundo das entranhas, sem razões nem silogismos, de defender sua filha... contra ela mesma [...]. O homem possui, é certo, direitos naturais irrefragáveis e imprescindíveis, somente entre esses direitos não está o de que os possa repudiar. Ninguém tem o direito de abdicar da sua liberdade [...] ninguém tem o direito de se fazer frade ou fazer freira como ninguém tem o direito de se fazer escravo... apelar à liberdade contra a liberdade é, pois, um sofisma torpe. ${ }^{43}$

\footnotetext{
${ }^{4}$ Por ironia do destino, cerca de 20 anos depois, Júlio de Matos e Bernardo Lucas (advogado de José Calmon no processo de interdição por demência da filha) voltaram a estar envolvidos num caso em que a psiquiatria tentou impor o seu ascendente sobre a Justiça. Tratou-se da célebre história do romance entre Adelaide Coelho, mulher do diretor do jornal Diário de Notícias, Alfredo da Cunha, e o seu motorista - situação que levou o marido a tentar uma interdição por incapacidade mental da mulher, chegando mesmo a interná-la durante dois meses no hospital para alienados Conde de Ferreira, com um atestado de Júlio de Matos. Por irônica coincidência, o advogado de defesa de Adelaide Coelho foi o mesmo Bernardo Lucas que, 20 anos antes, tinha estado ao lado de Júlio de Matos em favor da causa do cônsul do Brasil. Cf. Adelaide Coelho, Doida não! Documentação psicológica e jurídica, Porto, B. Lucas, 1920, e Idem, Doida não e não! [s...], [s.n.], 1923.

${ }^{42}$ Vejam-se as posições opostas, por exemplo, dos jornais monárquicos O Primeiro de Janeiro e Novidades, a partir do dia 18 de fevereiro e durante o mês de março de 1901.

43Sampaio Bruno, A Questão Religiosa, Porto, Chardron, 1907, p. 197; 202, itálicos do original.
} 
Para além da justificação histórico-científica, ou precisamente por causa dela, a crítica à alienação voluntária de uma suposta sociabilidade "natural" dos indivíduos revestiu-se também amiúde de contornos ético-morais: "quiseram convencê-la da indignidade. Ela já não percebia o que era isso",44 escrevia O Século, relatando os esforços com que, em vão, os pais de Rosa tentaram persuadir a filha a abandonar a ideia do recolhimento religioso.

Percebe-se que a percepção do religioso no republicanismo português estava algures mais além do consagrado princípio da separação "a Deus o que é de Deus, a César o que é de César". Na sua essência, a fórmula era uma das principais bandeiras da utopia republicana, mas, nessa sociedade secularizada, justa e democrática idealizada pelos republicanos, havia, na verdade, muito pouco de que César pudesse abdicar, muito menos em favor de Deus. Como bem notou Fernando Catroga, o projeto de laicização da sociedade encabeçado pela alternativa republicana implicava um "processo descristianizador totalizante", o que automaticamente tornava indissociável a confessionalidade do Estado da consubstanciação de uma mundividência laica, ${ }^{45}$ a tal ponto que, pela mão do republicanismo, a questão religiosa se fundiu no próprio projeto político e filosófico de criação de uma nova cidadania regenerada.

Por isso, a República portuguesa implantada em 1910 negou o modelo da "Igreja Livre no Estado Livre" e teve como prioridade a promulgação de uma lei da Separação da Igreja do Estado claramente destinada a destruir a hegemonia dos valores religiosos na sociedade, o que se compreende, pois, uma vez tendo o Estado um programa ideológico de aplicação no âmbito das consciências, a sua neutralidade deixá-lo-ia sempre em desvantagem em relação a outras instâncias concorrenciais.

É inegável que a secularização pensada pelo republicanismo português previa uma laicização não só da sociedade, mas também das consciências. ${ }^{46}$ E é precisamente no ponto em que esse objetivo se torna incompatível com uma mundividência religiosa que o anticlericalismo republicano se distingue do anticlericalismo liberal. Assim, compreende-se como - ao ser monopolizada pela agenda política e filosófica republicana - a questão religiosa passou a ser indestrinçável da questão de regime. Tudo isso decorreu lentamente no decurso de um processo que foi ganhando fôlego durante a década de 1890, para se incendiar na transição do século. O rastilho aceso pela jovem brasileira Rosa, em 1901, explodirá uma década mais tarde, numa guerra religiosa que comprometeu seriamente as hipóteses de sucesso da primeira experiência republicana em Portugal. ${ }^{47}$

\footnotetext{
44“O Caso Calmon”, O Século, 25 de fevereiro de 1901, p. 2.

${ }^{45} \mathrm{~A}$ expressão é de Fernando Catroga, "O laicismo e a questão religiosa em Portugal (1865-1911)", Análise Social, vol. XXIV, n. 100, 1988, p. 211-273; 226. Cf. Idem, Entre deuses e césares: secularização, laicidade e religião civil. Uma perspectiva histórica, Coimbra, Almedina, 2006.

46/dem, "Secularização e laicidade", Revista de História das Ideias, vol. 25, 2004, p. 114

${ }^{47}$ Quanto ao assunto, veja-se, sobre a questão religiosa em particular, a obra de referência: Maria Lúcia de Brito Moura, A guerra religiosa na I República, Lisboa, CEHR, 2010.
} 